\title{
MUSLIMS AND MODERNITY: AFTER TWO AND A HALF CENTURIES WHAT HAVE WE LEARNT?
}

\author{
A Meta-Study of the Main Lessons of \\ an Eventful Encounter
}

\begin{abstract}
Ali Paya*
Abstract: My aim in this paper is to explore, from an epistemic point of view, the main cause of the failure of the 'projects' introduced/developed by Muslim intellectuals/activists in response to the challenges posed by modernity/ postmodernity in the past two and a half centuries. The paper discusses four different responses by Muslim elites to the challenges of modernity and post-modernity. The paper suggests a conjecture concerning the main epistemological cause of Muslims underdevelopment and follows this by critically assessing one particular project, namely, Islamisation of Knowledge, as a typical case which exemplifies the conjecture in question.
\end{abstract}

The question which I intend to explore in this article is 'how much have Muslims learnt since their earliest encounter with the West and with modernity?' Perhaps a short answer to this question is: collectively, not much; at the level of individuals (including institutions), a limited amount.

The short answer may appear unpalatable, shocking or controversial to some. It may be objected that this is an overly pessimistic assessment of the achievements of Muslims in their encounter with the West.

There is no denying that in comparison to their situation in the $19^{\text {th }}$ century and the earlier parts of the $20^{\text {th }}$ century, Muslims have come a long way in terms of various developmental indicators, but even a quick look at the present state of Muslim countries and communities reveals that all is not rosy in the land of Islam.

A brief comparative study can reveal parallels and similarities between Muslims' sorry situation in the past and in present.

The following brief statistics from a recent paper entitled "Science in Muslim World: Where Do We Stand?" are self-explanatory:

The annual spending on science, research and development in Muslim countries is just 0.2 per cent of gross national product, its population of scientists is meagre, and its legal framework for innovation is largely non-existent. Compared to a world average of 1.4 per cent, the numbers of universities and research institutes are scanty in the Muslim world as compared to their available resources. Moreover, scientific/biomedical journals are fewer in number in the Muslim world and many of these journals do not have on-line access and are not indexed in major bibliographic databases. The majority of indexed journals, however, do not have a stable presence in the popular Pub-Med database. The 
Arab world contributes less than 0.5 per cent of scientific research papers appearing in the 200 leading medical journals. Furthermore, the number of publications, original writings and translations, per million people is around 0.05 in the Arab world compared with an average of 0.15 worldwide and 0.60 in the industrialised countries. ${ }^{1}$

Other indices of development make equally unhappy reading with regard to the status of Muslim countries and their citizens. After a lengthy analysis of the situation in various Muslim countries, the author of a recent paper on: 'Sustainable Development in Muslim Countries' warns:

If the Islamic governments are serious about sustaining long term economic development, and having recognised the partial and tilted government approach of the past half a century, they must embark on a process of comprehensive development. This process must tackle the formation of an appropriate level of human capital, both of the type that is embodied in individual market conduct and the type that is essential for creating developmental institutions and policies. ${ }^{2}$

Immediately before the above quote, the same author whose tone in the whole of his paper is overtly measured and conservative, issues a veiled warning, which is, in an indirect way, a good indicator of the 'situation' in Muslim countries. He says:

Corruption and favouritism... are important impediments to attracting capital from within as well as from without a given country, in addition to political risk and laxity on contract enforcement. When the laws of contract do not apply to everybody, entrepreneurial instincts tends to take advantage of favouritism instead of venturing productive projects, and both domestic and foreign savings shy away. ${ }^{3}$

But if, as the above evidence suggests, all is not well in the land of Islam, is it because Muslims have done nothing to improve their situation? Again the existing evidence challenges this assumption. On the contrary, even a cursory glance at the efforts made by Muslims since their earliest encounter with the West makes it abundantly clear that our forefathers left almost no stone unturned in their pursuit of solutions for overcoming Muslims' material and intellectual backwardness vis-á-vis the West. One can consider these efforts as 'projects' whose common aim was to change the lot of Muslims in the aftermath of their calamitous encounter with the West.

Various strategies adopted by Muslims in their effort to respond to the challenges introduced by the West and its models of modernity could be grouped into four very general categories, namely, isolation and/or rejection, conformity and/or assimilation, rivalry and/or confrontation, and constructive engagement and/or dialogue. To deal with the full range of Muslim responses to modernity and post modernity is a gargantuan task in which one may do well to heed the advice of Rumi, the great Persian poet: 


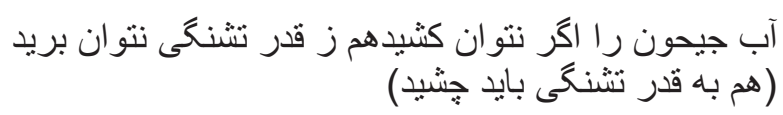

If it is impossible to drain (drink) the Oxus

One cannot deny one's self as much (water) as will slake thirst. ${ }^{4}$

In heeding Rumi's advice, I will use the broad brush of the four general categories introduced above to paint a rough picture of Muslim responses to modernity over the past two and a half centuries - despite the unavoidable shortcomings of such a broad sweep.

Now let me briefly explain the four general categories which were introduced above:

1. Isolationists/rejectionists are of the view that to save the soul of Islam and preserve the purity of Islamdom, Muslims should reject (to varying degrees) all things Western and should stick to Islamic tradition and teachings. Shaykh Fazlullah Nouri (1843 - 1909) in Iran, who was an ardent advocate of the thesis of mashrū 'a (priority of the Sharī'ah law) over mashrütah (constitutionalism) during the period which led to Iran's Constitutional revolution in 1906, is usually cited as a paradigm case for the isolationist/rejectionist approach.

When Hajj Mirza Hassan Tabrizi (Roshdieh - 1851-1944) introduced the first modern schools in Iran in 1886/7, isolationists/rejectionists did their best to thwart his efforts. They demolished some of his schools, bombed some others, threatened his life, even issued a fatwa to excommunicate him, and eventually forced him into exile. ${ }^{5}$ In a meeting with Nazim al-Islam, a prominent pro-constitution intellectual, Shaykh Fazlullah is reported to have said: "I beseech you to swear by the truth of Islam and tell whether this is not true that these modern schools are against religion, and whether this is not the case that enrolment in these schools leads to the annihilation of Islam, and whether this is not the case that studying foreign languages and chemistry and physics makes students renounce their religious beliefs". ${ }^{6}$

Another, more recent example of the isolationist/rejectionist approach is the movement led by Juhayman al-'Utaybiin Saudi Arabia in 1970s. Al-'Utaybi and his followers maintained, among other things, that the land of Islam and, in particular, the birth place of Islam, must be purified from the influence and even the presence of the infidels. In their bid to promote their message, they stormed the Mecca Mosque and took refuge in Ka'ba in November 1979. When all negotiations with Saudi authorities for a peaceful surrender failed, Saudi troops attacked the group members, killed most of them and captured some. ${ }^{7}$

2. Assimilationists/Conformists are of the view that emulating Western institutions, ideas and life styles provides Muslim societies with the best chance for turning their fortunes and catching up with modernity. Kemal Ata 
Turk in Turkey and Reza Khan in Iran were two prominent representatives of this trend.

While the assimilationists/conformists have been criticised by both conservative and revolutionary Muslims for their overture towards the West, it is only fair to say that they have played a major role in facilitating the transition of Muslim societies from pre-modern conditions to modern conditions. Many of the institutions of the modern world, such as universities, research institutes, modern systems of judiciary, and modern social etiquettes were introduced to Muslim societies by assimilationists/conformists.

3. Confrontationists subscribe to the thesis of Islamic supremacy. Sayyid Qutb in Egypt who maintained that the West is the embodiment of the modern jāhilliyah, Abu al-Ala Maududi in Pakistan, and Rashid Rida in Egypt, each with his particular approach, are three of better known representatives of this trend $^{8}$. Some of the trends in the Islamic revolution of 1979 in Iran could also be regarded as examples of a supremacist interpretation of the saying of the Prophet that: الاسلام يعلو و لا يعلى عليه - Islam prevails and is second to none. In recent years groups such as the Taliban, al-Qaeda, Salafis and Jihadists have pushed the confrontationist agenda to some extreme limits far beyond what the earlier figures in this trend had explicitly recommended.

4. The proponents of dialogue, as the name of their orientation suggests, hold that a give and take relationship between Islam and the West is not only possible but also greatly desirable. Sir Sayyid Ahmad Khan and his colleague and friend Aga Khan III in India, founders of the Aligarh Muslim University, Mohandes Bazargan in Iran, and Mohammad Iqbal in Pakistan, among others, represent earlier generation of the advocates of this trend. Many modern day reformers in various Muslim countries subscribe to this approach.

\section{What Went Wrong? Concerning the Main Epistemological Cause of Muslims' Underdevelopment}

Proponents of each of the above strategies have made many efforts to bring about the success of their visions. They have tried to train dedicated cadres, made use of modern technologies, established various research centres and universities, published books, newspapers and magazines, set up radio and TV stations, made deals with powers that be, and in some cases have even resorted to violence.

The impact of these general trends on Muslim societies has been considerable. Muslims in this day and age, are much better educated than their forefathers in the $19^{\text {th }}$ century and the earlier decades of the $20^{\text {th }}$ century. The average income of Muslim households in our time is higher in real terms than what was the case a century ago. More Muslims have visited the West (or have been born in the West or lived in the West) in recent decades in comparison to the visits made 
by Muslims in the previous decades. More Muslims are familiar with modern Western languages than ever before. While in the earlier parts of the twentieth century only a small number of Muslims had been appointed as high ranking civil servants or company managers or academic staff in Western countries and institutions, the number of Muslims in such positions has increased manifold in recent decades.

The list of such positive achievements can continue with more interesting entries, and yet when we look at the Muslim world at present, we see new incarnations of the same old problems which marked the earlier encounters between the West and Islam. After two and half centuries, Muslims still talk about the difficulties they have with modernity. Still we observe that when it comes to Muslims' response to modernity, the categories listed above can be usefully employed in order to make sense of the current situation. In other words, it seems that Muslims, despite all their efforts to come up with effective solutions for dealing with the 'problem' of modernity, have, to a large extent, moved in a circle. Or, to be more accurate, given the fact that modernity itself is ever evolving, in a single-plane spiral.

Many writers have tried to explain the above, rather perplexing phenomenon. These explanations, notwithstanding all their sophistications, still leave much to be accounted for with regard to the present state of Muslim societies in the larger family of world's nations.

For my part, the most I can hope to do is to propose a conjecture concerning one of the causes that I suspect may have been playing a significant role in perpetuating this rather unhappy state of affairs.

The cause I am going to propose deals with the phenomenon of encounter between Muslims and modernity from an epistemological point of view and focuses on Muslims' state of knowledge. My conjecture is as follows:

While many external factors have adversely impacted Muslims' ability to rise to the challenges introduced by modernity, when it comes to internal factors, i.e. causes from within Muslim cultures and traditions that have hampered their efforts in developing appropriate responses to modernity, two factors stand out. The first is what may be dubbed 'the underdevelopment of critical and rational thinking as a way of life among Muslims since their encounter with modernity'. The second is over-reliance on technology, including religious technologies (which I'll explain shortly) as well as technologies borrowed from the West, at the expense of developing knowledge about reality (including socially constructed realities).

By "critical and rational thinking way of life" I mean a way of life informed by a particular theory of knowledge which can be defined in terms of a number of axioms/statements, including the following, which only highlight some, though not all, aspects of this theory: 
1. All knowledge is conjectural;

2. In pursuit of knowledge, what is important is the growth of knowledge and not any momentary state of knowledge per se;

3. Knowledge grows through critical assessment by means of analytical appraisal and empirical testing;

4. We improve our knowledge about reality, whether natural or socially constructed, by learning through our own mistakes or the mistakes made by others;

5. Critical assessment in the public arena can lead to conjectures/knowledge claims which are objective and corroborated, but never justified or certain.

The above provides us with a minimal understanding of the philosophy known as critical rationalism. Let me also explain the way I define technologies, including the so-called religious technologies, before going back to my main conjecture.

Technologies are man-made constructs which serve two main purposes. ${ }^{9}$ On the one hand, they respond to our non-cognitive needs. Clothes, cars, houses, foods, are examples of this type of technology. On the other hand, technologies can act as tools or instruments to assist us with our cognitive needs. This is a need to which knowledge or science, which is distinct from technology, responds. Telescopes, microscopes, laptops, reading-glasses, books, pens, etc., are examples of this second type of technology. Of course, some technologies could serve both purposes. A mobile phone for example can respond to our need of socialising; it can also help a doctor to receive vital information concerning the health of his/her patient.

Religious technology, as the name indicates, is defined in the sphere of religion. All religions are based on a single premise, namely, the whole realm of being has a Master or Lord and is not on its own. To this ontological axiom corresponds an epistemic one, namely, the Master of the realm of being is, in principle, knowable by us mortal beings who have limited cognitive abilities. Apart from knowledge claims concerning the above ontological premise, all other aspects of religions are technologies. Such religious technologies include rituals, methods of worship, etiquettes, and their ilk; they either respond to the believers' non-cognitive needs, for example the need for social cohesion or group solidarity, or facilitate, as tools, their cognitive needs in better knowing the Master of the realm of being ${ }^{10}$.

Well, having clarified some of the main aspects of my theoretical approach, I can now, go back to unpack the conjecture I stated above.

My claim is that in their encounter with modernity, Muslims have not fully appreciated the importance of improving their critical and rational attitude, and at the same time they have over-relied on all types of technologies that respond mostly to their non-cognitive needs.

It must be stated at this juncture that the critical and rational way of thinking was never alien to Muslims in the past centuries and prior to the encounter of 
Muslims with modernity. The likes of Mohammad ibn Zakariya Razi (865925), Abu Rayhan Biruni (937-1048), Ibn Rushd (1126-1198) and Fakhr Razi (1149-1209) kept the spirit of scepticism about the 'received wisdoms' of the day alive. Moreover, despite the fact that fuqahā' (jurists) were doing their best to impose their views as the 'official way of understanding' Islamic teachings, other scholars, e.g. mystics, philosophers, and theologians, were constantly challenging the 'official reading' and thus were preserving a degree of plurality in the Islamic cultural eco-system.

Nevertheless, even during the Golden age of Islamic civilisation (750-1258) the spirit of rational and critical thinking did not fully develop. After this period, and no doubt partially as a result of foreign invasions as well as infightings among Muslims themselves, dissent became even more difficult. Moreover, some disciplines, such as Sufism, turned inward and developed closed systems in which rational discussions did not have a strong position.

Going back to the story of the encounter with Modernity, it should be noted that Muslims' immediate concern in the aftermath of their defeats at the hands of the West was to achieve military and technological competence. All the efforts made in all Muslim countries were geared towards this aim. For example, the first Iranian students who were dispatched to Europe in $19^{\text {th }}$ century after the first Russo-Persian war studied in technical, military, medicine and engineering fields. But none was asked to study philosophy or humanities and social sciences. ${ }^{11}$ In our times, even those Muslim groups who overtly oppose Western ideas and ideals, such as the Taliban, have no hesitation in making use of the latest Western gadgets, though they fiercely reject Western philosophies.

As far as religious technologies are concerned even a cursory glance at the history of Muslim societies in the past two and half centuries clearly shows that various religious technologies have been used by different Muslim groups in order to promote their brand of Islam and consolidate their position in the eyes of the masses. Among religious technologies, fiqh, 'irfän (mysticism), and various rituals (mostly performed as a routine practice rather than as a novel adventure aimed at enhancing knowledge of God) have been dominant disciplines in all Muslim countries. Among non-religious technologies, the drive for Western style modernisation can be singled out as a prevailing trend in the land of Islam.

One of the main implications of my conjecture is that Muslims, due the fact that second-order thinking and critical rationalism has remained underdeveloped among them, have not been successful in learning from their mistakes or the mistakes made by others in dealing with emerging aspects of modernity.

A case in point may be seen in the tragic consequences of the two recent instances of Islam-bashing that have been seen in the anti-Prophet movie shown on YouTube and the cartoons appearing in a French satirical magazine. Muslims 
have been here before. When the book Satanic Verses was published in 1988, and when a Danish newspaper published a series of cartoons insulting the Prophet in 2005, we witnessed similar demonstrations of anger, and the unfortunate and regrettable loss of innocent lives across Muslim lands.

Despite the fact that such reactions have occurred to no effect in the past, Muslims collectively went along repeating them, yet again. What did not materialise, in a systematic and coordinated manner, were responses in tune with the requirements of a modern age, such as, for example, law suits in Western courts (the courts of countries in which the offensive acts originated) against the perpetrators of such blatant abuses, or measured campaigns for informing the public in the West and in the East of the injustices done to Muslims. And this despite the fact that Muslims have created institutions such as the Organisation of the Islamic Conference, now known as the Organisation of Islamic Cooperation, and that Muslim countries have a strong presence in the United Nations and other important international bodies, and that some of Muslim states have large financial resources which would enable them to cover the cost of law suits or media campaign.

The underdeveloped state of critical rationalism in Muslim societies and the failure to learn through and from mistakes can also be viewed as an example of the 'cargo cult' mentality. Richard Feynman has described this mentality, in the context of a non-Muslim culture, in the following way:

...In the South Seas there is a cargo cult of people. During the war they saw airplanes land with lots of good materials, and they want the same thing to happen now. So they've arranged to make things like runways, to put fires along the sides of the runways, to make a wooden hut for a man to sit in, with two wooden pieces on his head like headphones and bars of bamboo sticking out like antennas - he's a controller and they wait for airplanes to land. They are doing everything right. The form is perfect. It looks exactly the way it looked before. But it doesn't work. No airplanes land. ${ }^{12}$

Many of the institutions which are created in Muslim societies to deal with the trials and tribulations of the modern world are more like simulacra than the genuine article. A case in point are the 'Human Rights Commissions' in many Muslim countries.

Even when a modern mechanism is being used in an effective way by some groups of Muslims, their successes do not seem to prompt other Muslims to adopt these successful approaches. Three examples which come to mind are the Aga Khan University which is a shining example of a successful academic institution, al Jazeera, a successful news network, and Gulen's dialogue movement, which promotes dialogue among religious and non-religious people.

But perhaps one of the clearest cases of neglecting the spirit of critical and rational thinking is the project of producing Islamic or sacred knowledge which 
apparently has obsessed many Muslims since late 1950s in the heyday of the liberation movements in the third-world and the peak of the so-called discourses of third-worldism and authenticity. In the remaining part of the paper, I briefly, though critically, assess the project of Islamisation of knowledge.

\section{Islamisation of Knowledge}

There is no doubt that in its earlier stages, the project of producing Islamic science was in part a response to the identity problem which had become an acute problem in many third world countries. It was also a response to the arrogance of the West in its dealing with Muslims and Muslim countries. When Professor Seyyed Hossein Nasr tried to publish his $\mathrm{PhD}$ thesis, Science and Civilization in Islam (Harvard UP, 1968) in which he had argued against the accepted view that Muslims were only transmitters of the Greek sciences to the West, and that they added nothing original, he encountered stiff resistance from many quarters including his own supervisor the famed Giorgio de Santillana.

Similarly when the late Professor Ismail Faruqi (1921-1986) launched his comprehensive project of 'Islamisation of Science' his aim was, as he himself stated, to fight against loss of identity among Muslims:

There can be no doubt that the main locus and core of the Ummah's malaise is the prevalent educational system. It is the breeding ground of the disease... It is in schools and colleges that self-estrangement from Islam and from its legacy and style are generated and perpetuated. The educational system is the laboratory where Muslim youth are kneaded out, where their consciousness is moulded into a caricature of the West. ${ }^{13}$

However, despite the pious intentions of all those who have been involved in the project of Islamisation of science, generating an Islamic or sacred science, the sad fact is that these projects, which have many things in common, are all misguided ventures based on a misunderstanding of the nature of science and a conflation of science and technology. Such wrong-headed ventures have mushroomed in Muslim countries and each year hundreds of millions of dollars are spent for developing them, something that may be viewed as an indicator of the underdevelopment of a critical and rational attitude among Muslims.

One particular project of Islamisation of science which I will briefly introduce and criticise here is called the Ijmali project. It is the brain child of Ziauddin Sardar (a scholar, cultural critic and broadcaster based in London), Parvez Manzoor (a Swedish-based writer and scholar), and Munawar Ahmed Anees (a Pakistani-American writer and social critic).$^{14}$

The term Ijmali as Sardar and his colleagues suggest comes from ijma', social consensus and $j m l$, beauty/wholeness. It seeks to synthesise 'pure knowledge' with 'moral knowledge'. Its guiding principles are social consensus (ijma'), trusteeship (khiläfah), public welfare (iștilāh) and reason ('aql) ${ }^{15}$. 
The Ijmalis compare their model of Islamic science with what they call Western science in the following way ${ }^{16}$ :

\begin{tabular}{|c|c|c|c|}
\hline & Western Science & & Islamic Science \\
\hline$»$ & Puts its faith in rationality & $»$ & Places its faith in revelation \\
\hline$»$ & $\begin{array}{l}\text { Values science for the sake } \\
\text { of science }\end{array}$ & $»$ & $\begin{array}{l}\text { Sees science as a form of worship } \\
\text { which has a spiritual and a moral } \\
\text { function }\end{array}$ \\
\hline$»$ & $\begin{array}{l}\text { Posits one all-powerful method as } \\
\text { the only way of knowing reality }\end{array}$ & $»$ & $\begin{array}{l}\text { Uses many methods based on reason } \\
\text { as well as revelation }\end{array}$ \\
\hline$»$ & $\begin{array}{l}\text { Claims impartiality - to be value free; } \\
\text { a scientist is not responsible for the } \\
\text { use to which his/her work is put }\end{array}$ & $»$ & $\begin{array}{l}\text { Claims partiality - towards the truth; } \\
\text { consequences must be morally good }\end{array}$ \\
\hline$»$ & Claims the absence of bias & $»$ & Admits the presence of subjectivity \\
\hline$»$ & $\begin{array}{l}\text { Reduces the world to what can be } \\
\text { empirically verified }\end{array}$ & $»$ & $\begin{array}{l}\text { Admits the reality of the spiritual } \\
\text { dimension }\end{array}$ \\
\hline$»$ & Is fragmented into disciplines & $»$ & $\begin{array}{l}\text { Values synthesis, is multidisciplinary } \\
\text { but holistic in its approach }\end{array}$ \\
\hline
\end{tabular}

The above table, though only contains some of the main theses of the ijmali model, suffices to show the extent to which ijmalis, and others who share many of the above claims, have committed category mistakes and conflated issues which are related neither to science or knowledge nor to a sound understanding of Islam.

For example the claim that the so-called Islamic science 'places its faith in revelation' tells nothing substantive or worthwhile. On one reading, i.e., if it is taken to mean that Islamic science accepts apparent meaning of revelation in a blind manner, it can promote a dangerous epistemic attitude. On another reading, i.e., if it is taken to mean that it accepts revelation, as a potential source of knowledge, then it says nothing special. The reason is that when a researcher uses revelation or any other potential source of knowledge, for that matter, he/she must interpret it. Interpretations are, inevitably, conjectures made by fallible human beings. As such they cannot be perfect representations of reality. Their shortcomings must be disclosed in the public arena and through critical assessments. But this is exactly what modern science does with all potential sources of knowledge, including revelation.

The claim that Islamic science 'sees science as a form of worship which has a spiritual and a moral function' betrays other types of confusions. Worship, as explained above, is a form of technology. It assists the believer in his/her pursuit 
of knowing the Master of the realm of being. Moreover, as critical rationalists argue, science/knowledge and morality go hand in hand. In the absence of a moral attitude the chances of improving our knowledge about reality are drastically reduced. ${ }^{17}$

The claim about modern science, namely, it 'posits one all-powerful method as the only way of knowing reality' is simply false. First of all, methods, as explained earlier, are all technologies. And technologies do not provide us with knowledge and are not ways of knowing reality. Methods can only assist us in our knowledge pursuits as tools. What tell us about reality are our conjectures. Secondly, science uses many different methods. There is not just one single method used in science. Thirdly, the idea that knowledge can be acquired by means of applying one powerful method is based on the mistaken idea that knowledge-garnering process is reducible to algorithmic or rule-following procedures. However, knowledge, as we have seen earlier, is the sum-total of our corroborated conjectures. Conjectures are the products of creative imaginations and not following set rules.

Other tenets of the ijmali model such as that 'Islamic science claims partiality towards truth', or is 'holistic in its approach'; or that modern science 'reduces the world to what can be empirically verified' or that it 'claims absence of bias' are all either confused or mistaken.

Truth is the only aim of knowledge/science. All other aims, including worship, improving social condition, changing the environment, becoming famous, getting rich, etc. belong to the realm of non-cognitive needs, namely, the realm of technology. Holistic approach is a misnomer. Every whole has infinitely many parts. It is impossible for creatures with limited cognitive ability like us to know the whole. We can only come to know a reality which we regard as a whole in a piecemeal manner by focusing on selective aspects of reality.

Verification was the hallmark of positivism. Modern science in recent decades, thanks to critical rationalist philosophers of science, has learnt to steer clear from positivism as much as it can. However, unfortunately almost all of the proponents of various projects of Islamisation of knowledge/science have mistakenly adopted the positivist image of science as the only valid image of science.

Biases, prejudices, preconceptions, foreknowledge, etc. are baggage that we all carry. We simply cannot think in a vacuum. Nevertheless, science aims at objectivity by making all its knowledge claims publicly accessible and publicly assessable. Through never-ending processes of critical assessment in the public arena residues of biases, prejudices, preconceptions and the like which might have been smuggled into the formulation of knowledge claims are detected and removed. At the end, what remains is mostly, though perhaps not perfectly, about reality and not particularities of the subjective attitudes of this or that scientist. 
Criticism of the views of ijmalis and other advocates of the project of Islamisation of science could go on and on, but it should be clear from this alone that the underdevelopment of a second order critical approach in Muslim countries has resulted in the underdevelopment of the ability of Muslim elites and public alike to learn from their own mistakes and the mistakes of others. A misguided conception of reverence towards the elders or people of prominence or sets of dogmatic interpretations, has resulted in sacrificing the pursuit of truth via critical assessment of the views and behaviours of those who are in positions of power, and up-holding wrong-headed ideas and ideals.

Islam at its inception heralded a critical and rational way of dealing with entrenched dogmas and mistaken views. Many of the verses in the Qur'an warn Muslims about idol-worshipping and remind them of the importance of acting as iconoclasts. It is rather ironic that despite all the calls for revival of the true spirit of Islam in all Muslim countries and among different groups of Muslims, the neglect of the critical and rational attitude, which is a true Islamic attitude, has caused Muslims all sorts of suffering in their encounter with modernity.

\section{Conclusion and Policy Recommendations}

Muslim responses to modernity and postmodernity have been through an assortment of 'projects' developed by various actors in different socio-political and cultural milieus in Muslim countries. The common objective of all these diverse projects, despite differences in strategies and tactics, has been to meet the challenges posed by the eventful encounter between a 'Modern West' and a 'World of Islam' that, by and large, had been on holiday from history for a few centuries.

As arbitrary dates for marking the initial stages of this 'encounter', which apparently is still on-going, one can cite Napoleon's invasion of Egypt (17981801) or the first Russo-Persian war (1804-1813) or even the Battle of Plassey in 1757 which marks the beginning of the consolidation of the power of the East India Company in India.

Since the early stages of the encounter many writers, Muslim or non-Muslim, scholar or activist, have tried to register and record their observations and reflections on those aspects of the encounter they have witnessed or have found worthy of attention. The result of all these reports and analyses is a wealth of information concerning a large scale human drama which started almost two and a half centuries ago and has given rise to a myriad of diverse phenomena.

Muslims in their long experience with various manifestations of modernity, itself an evolving phenomenon, have come up with a variety of responses, but this rich store of trials and errors has remained under-used. Successive generations of Muslims in different Muslim societies have failed to study critically and assess the experiences of their predecessors and learn from their mistakes, or through 
their own mistakes. While pockets of rationally enlightened and historicallyinformed activities can be seen here or there, a large number of Muslims are still engaged in practices which at best can be regarded as 'reinvention of the wheel', and at worse 'production of misguided schemes'.

The so-called 'Islamisation of knowledge/producing Islamic science', one particular project which has received a great deal of attention in many Muslim countries, is representative of this situation.

\section{Recommendations:}

- For Muslims to overcome their present disadvantageous status, extensive programmes which aim at promoting a critical and rational understanding of modern ways as well as traditional thinking need to be promoted and pursued by Muslim elites and intellectuals.

- From an epistemological point of view, Muslims have not been particularly successful in developing second order disciplines that is, disciplines which critically and rationally look at the outcome of first-order disciplines. In an intellectual environment in which second-order knowledge is underdeveloped, the growth of first-order knowledge will also be adversely affected.

- From an epistemological point of view, a way forward for Muslims to be able to get engaged with modernity in a constructive and effective manner is to promote critical and rational understanding among not only the elites but also the grass roots in Muslims societies.

- For these programmes to be successful, novel, and 'user-friendly' approaches need to be devised. This task, first and foremost, is the responsibility of the Muslim intellectuals who represent a new social force in Muslim communities; a new breed of experts who are well-versed in both modern and traditional ideas and capable of developing and managing institutions which are fit for the above-stated purpose.

\section{Notes}

* Ali Paya is a Senior Visiting Research Fellow at the Department of Politics and International Relations. He is also Associate Professor of Philosophy at the National Research Institute for Science Policy in Iran. His research interests include Muslims' Intellectual Legacy (including Muslim Social and Political Thought); Philosophies \& Methodologies of Social and Human Sciences; Cultural, Social and Ethical Impact of Modern Sciences and Technologies; and Futures Studies.

1. Sultan Ayoub Meo and Adnan Mehmood Usmani, "Science in Muslim World: Where Do We Stand?", Pakistan Association of Medical Editors, 3-5 Dec. 2010. http://www.pame.org.pk/emmj5/program.html

2. Monzer Kahf, "Sustainable Development in Muslim Countries", p. 48. http:// monzer.kahf.com/papers/english/Sustainable_development_Revised_First_ 


\section{Draft.pdf}

3. Ibid.

4. The Mathnawi of Jalulddin Rumi, Edited and Translated by Reynold A. Nicholson, London, 1933, verse 66, book VI.

5. Shams al-Din Roshdieh, SavnihOmr (Trials \& Tribulations of Life). Tehran: Nashir-e Tarikh, 1983; Hossein Sabeti, "School bell is the same as church bell', Louh, Vol. 5, 1999.

6. Nazim al-Islam Kermani, The History of Iranians ' [political] Awakening, Tehran, 1983, vol. 1, sec. 1 .

7. Thomas Hegghammer and Stephane Lacroix, "Rejectionist Islamism in Saudi Arabia: The Story of Juhayman al-“Utaybi Revisited”, International Journal of Middle East Studies, vol. 39, no. 1, 2007, pp. 103-122.

8. For the views of Qutb, Maududi, and Rida, see: Ali Rahnema (ed.), Pioneers of Islamic Revival, Zed Books, 2005; Charles Kruzman, Modernist Islam 184 1940: A Source Book, Oxford University Press, 2002.

9. Ali Paya, "How indigenous are 'indigenous sciences'? The Case of 'Islamic Sciences", in Asia, Europe, and the Emergence of Modern Science: Knowledge Crossing Boundaries, edited by Aron Bala, Palgrave, 2012.

10. For a thorough assessment of the notion of religious technology, see, my paper, "Religious technology: Meaning \& Possibility" in, Ali Paya, Religious Science and Technology: Critical Assessments, ICAS Press, 2014.

11. Farzin Vahdat, God and Juggernaut: Iran's Intellectual Encounter With Modernity, Syracuse University Press, 2002.

12. Feynman, You Must be Joking Mr. Feynman, Viking, 1985, p. 340.

13. Ismail al-Faruqi, "Islamization of Knowledge: Problems, Principles, and Perception", in Islam: Source and Purpose of Knowledge, The International Institute of Islamic Thought, 1982, p. 22.

14. In fairness to the above authors, two of whom (Sardar and Manzoor) are my dear colleagues; I must hasten to add that they are all critical thinkers in their own fields. In fact, Sardar, has been in charge of an important Quarterly, Critical Muslim, which aims at promoting critical thinking among Muslims. Nevertheless, with regard to their joint project of Islamisation of science, as I hope to show below, it seems they greatly lowered their critical guards.

15. Clinton Bennett, Muslims and Modernity: An Introduction to the Issues and Debates, Continuum, 2005, p. 119.

16. Ibid., p. 120.

17. See Karl Popper, Open Society and Its Enemies, Routledge, 2 Vols., 2011. 